\title{
Approaches to the formation of energy service markets in developing countries
}

\author{
M. Kozhevnikov \\ Department of Energy and Industrial Management Systems, \\ Ural Federal University, Russia
}

\begin{abstract}
The majority of developing countries are experiencing similar problems in the formation of an energy service infrastructure after reforms in the electric power sector. These problems are connected with spontaneous competition between energy service companies, ensuring the growth of their business efficiency and reduction in the quality of provided services. The purpose of this study is to develop an appropriate model for the energy service market. It was determined that the development of market mechanisms in the energy service contains three main pillars: the legitimization of service activities, the optimization of market structure and the development of staff capacity in energy service companies. Also the importance of involving energy service companies in the process of creating organizational and economic innovation in the industry was proved. As a part of the analytical tools a technique that provides an estimation of the capacity of an energy service market was developed.

Keywords: energy service, energy efficiency, market development, reform design, market capacity, demand-side management.
\end{abstract}

\section{Introduction}

A large number of developing countries were reforming the electricity industry in the 1990s and the first half of the 2000s, and the main purpose of this restructuring was to attract private investment in the sector. During this period particularly Asian countries have experienced unprecedented economic growth, which is directly reflected in the growth rate of energy consumption. For example in China for the first four months of 2003 it amounted to $16.3 \%$, three times higher than expected, resulting in more than half of the Chinese provinces 
received limited portions of electricity throughout the year [1]. A lack of state funds to provide the necessary electric power development coupled as well as high depreciation of fixed assets proved necessity of reform. This is the difference between the reform process in the power sector in developing and developed countries - in recent reforms started under favorable conditions (large reserves of generating capacity, low energy consumption growth, the possibility of widespread use of cheap natural gas, a powerful energy infrastructure) and carried out in order to reduce the price of electricity [2].

Usually the appearance of the wholesale and retail electricity markets is taken as the main result of energy reforms, though the most natural industry object of market relations is energy service market. Unfortunately, practically all developing countries do not take into account the specifics of the market when designing reforms. As a result its development is slow, spontaneous competition between energy service companies leads to a decrease in the quality of services and priority is given to financial indicators rather than to indicators of reliability. At the same time under conditions of high depreciation of fixed assets energy service companies become a key driver of electric power development. They also provide a support for the innovative development of the industry as they are actively involved in the implementation of complex industrial projects, such as demand-side management programs.

That is why it is necessary to create such organizational and economic energy service market mechanisms that can ensure progress in the industry, taking into account the processes of technological modernization and updating and provide balance between the commercial results of energy service companies, as well as the requirements for reliability and energy efficiency. Thus, this study is relevant to many developing countries in which the energy service market is in its infancy.

\section{Problems in the organization of energy service markets in developing countries}

The energy service market is treated in this study as a system of economic relations between customers (utilities, industrial enterprises, businesses and individuals) and energy service companies, based on the principles of competition and active cooperation of market participants, and related to the development, sale and consumption of professional service products. The main segments of the market are repair, modernization and reconstruction of power facilities; maintenance and installation of equipment, providing energy conservation and efficiency projects; energy consulting: information and diagnostic services; engineering; training.

The main market player - Energy Service Company (ESCO) - sells services to increase the energy efficiency of objects or processes, making a profit from the achieved energy savings. Also the market is represented by professional repair organizations, manufacturers of power equipment and finally, the power company can provide various services itself. 
The process of interaction between customers and the energy service market players is based on a general business principle: each subject tries to minimize costs (resources) on the production and maximize the commercial effect, at the same time all the interests of the consumer should be satisfied, because it is the key to competitiveness. Meanwhile, interests of the end-user in developing countries are usually taken into account to a lesser extent (for various reasons, mainly institutional), which leads to a number of negative effects:

- in the power utilities the main negative effect is expressed in the growing dependence of their own financial results from sales of the main product (electricity), and not from the sale of related services, which leads to a lack of innovations and poor customer orientation;

- $\quad$ on the ESCO level there is a loss of interest in the quality of service, entrepreneurship, technological renewal;

- negative impact on the end user is expressed in an increased risk of power supply reliability, as well as the limited market supply.

Table 1 shows the additional barriers ESCOs faced in their work. These barriers are common to all developing countries

Table 1: Barriers to energy service market in some developing countries [3].

\begin{tabular}{|c|c|}
\hline Country & Barriers to consider \\
\hline China & $\begin{array}{l}\text { The overall scale of the ESCO industry is relatively small compared to } \\
\text { the great demand for the energy service and market requirements. Most } \\
\text { of the ESCOs lack financing methods, technical capacity and provision of } \\
\text { solutions for customers. Although there is a lack of professionals to } \\
\text { manage the projects. }\end{array}$ \\
\hline India & $\begin{array}{l}\text { The ESCO concept is still relatively unexplored in India. The absence of } \\
\text { big players, the limited financial ability and inadequate past experience } \\
\text { cause ESCOs to seem untrustworthy to energy end-users. The actual } \\
\text { public procurement system has drawbacks and several ESCOs consider it } \\
\text { as being very complicated. }\end{array}$ \\
\hline Malaysia & $\begin{array}{l}\text { Energy services usually come with a high price tag and industries are } \\
\text { reluctant to invest in activities that do not have visible benefits to } \\
\text { productivity or profit levels. The conventional financial loans are not } \\
\text { viable for energy efficiency projects because of the government subsidy } \\
\text { of energy prices. At last, there are problems with certification of ESCOs } \\
\text { and lack of energy professionals. }\end{array}$ \\
\hline Russia & $\begin{array}{l}\text { Energy service market in Russia is still underdeveloped. The small } \\
\text { ESCOs focus mainly on energy efficient solutions for the oil and gas } \\
\text { industries, as well as energy-efficient lighting systems. The main } \\
\text { problems faced by ESCOs in Russia - a lack of funding, corruption } \\
\text { (imperfect tender system), high energy affiliation with energy utilities, } \\
\text { poorly developed range. }\end{array}$ \\
\hline Thailand & $\begin{array}{l}\text { Companies are reluctant to invest in energy efficiency projects when the } \\
\text { first project did not prove itself to be a good investment. Besides many } \\
\text { clients seemed to believe that they could handle the energy efficiency } \\
\text { technical risk by themselves. }\end{array}$ \\
\hline $\mathrm{V}_{1}$ & $\begin{array}{l}\text { There are insufficient legal guidelines/directives to support energy } \\
\text { efficiency activities. Still payment based on the results of savings is } \\
\text { perceived by and-users as high risk. }\end{array}$ \\
\hline
\end{tabular}


The real (and key) problem in the organization of an energy service market in developing countries is the lack of the owners strategic vision about the service business model to harmonize economic interests of the major market actors. This problem causes a number of negative trends that penetrate to the level of specific energy companies. Decomposition of problems is presented in Fig. 1.

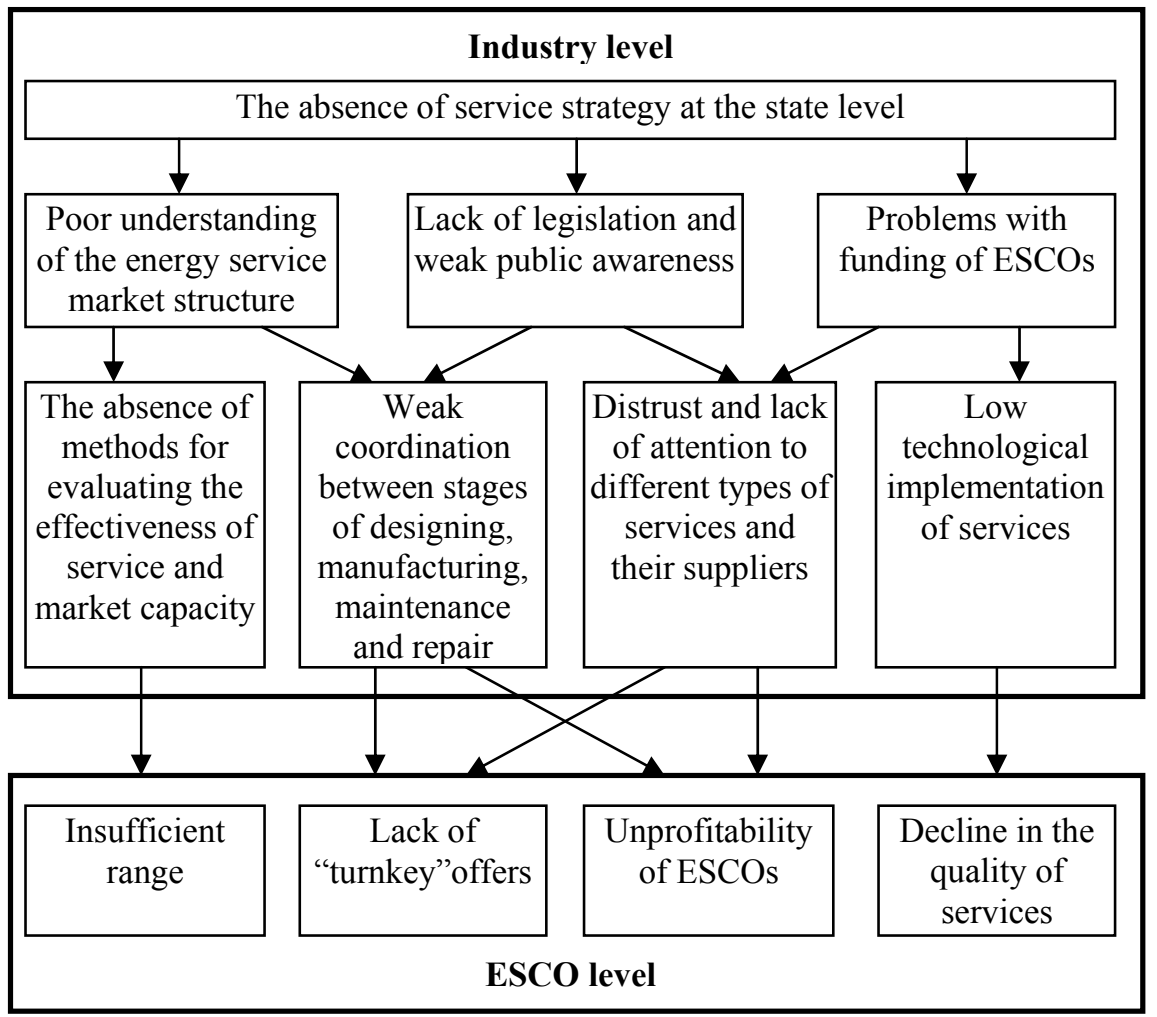

Figure 1: Factors hindering the development of ESCO industry.

\section{The model of energy service market}

Analysis of the problems in the organization of energy service markets in developing countries reveals the key directions of the development of market mechanisms.

1. Legitimization of market (improvement of the existing legal framework, development of mechanisms of interaction between ESCOs and international organizations, formation of an energy service quality standards, establishing procedures for the licensing, development specific financial incentives schemes).

For example, the first three Chinese ESCOs began their work in Beijing in 1997 with financial support from the World Bank, the European Commission 
and the Global Programme of Environmental Protection. Company can get the status of ESCO if it meets four criteria:

- it is an independent entity whose activities are connected with the implementation of energy efficiency projects;

- it makes economic transactions in the status of a legal entity for at least 12 months;

- company's share capital is not less than 1 million yuan;

- it has implemented at least one energy-saving project and the amount of savings achieved by the project was at least 1 million yuan.

At the same time in Russia, which has a high potential for energy service market, due to a complete lack of appropriate legislation (the first attempt to legalize ESCOs was made in 2009 with the advent of the law "On Energy Saving", despite the fact that the reforms in the electric power industry conducted from the beginning 2000s.), market regulation and financial support energy efficiency projects seemed to be high-risk for most financial institutions. It complicates the task of finding customers and automatically reduces the demand for energy services.

2. The market structure optimization (identifying unfair providers of energy services, providing market audits and recommendations to improve the service efficiency in the regional power systems, formation of ESCO ratings).

Among the problems to be solved in this area it is necessary to declare the support for small energy service business. For example, in China, which has similarities with the Russian power system, more than a half of ESCO are small enterprises, and only $12 \%$ are large, almost all of them are subsidiaries of territorial power utilities [4].

3. Human resource development (formation of special education programs and technologies, training and retraining of specialists in universities and enterprises, the creation of competence centers of energy services). For some countries, such as Russia, the actual measure is the establishment of minimum wage for ESCO industry workers at a level not lower than the regional average.

These market mechanisms must be implemented by the profile ministries, large energy companies, energy machinery and industrial enterprises. Due to the scale of the problems arising in the formation of the energy service market, as well as on the basis of research experience in the development of such markets in some countries [1,5-8] a special independent structure should be created. This structure must take responsibility for the market regulation and coordinate the various actors of the market.

A number of important principles and tools that form the market model and contribute to its development should be noted:

- large energy service market players act as system integrators, assuming the risk for ongoing activities, capable to implement complex engineering, energy efficiency and innovative projects, repair and reconstruction of complex equipment; 
- providing trouble-free operation of the equipment (integrated management of reliability, energy efficiency and environmental performance) may become one of the source of ESCO income. Economically, it can be expressed at an extra charge for additional warranty for maintenance services;

- interdisciplinary character of the service function requires a methodological support of service activities. In this case, creation of special competence centers could be progressive solution. It is possible to accumulate and replicate the service experience, realize staff training, improve the technical conditions and the different characteristics of the equipment database within such centers.

The problem of forecasting the size of energy services markets also can be solved in competence centers. This study has developed and successfully tested in a number of Russian enterprises technique allowing to assess market capacity using objective information available. The technique consists in the transition from basic market segment to market-substitute, the dynamics of which is easy to learn from open sources and completely determines the projected demand for product groups of valued segment [9]. Sequence of evaluation is shown in Fig. 2.

Main actions

Additional actions

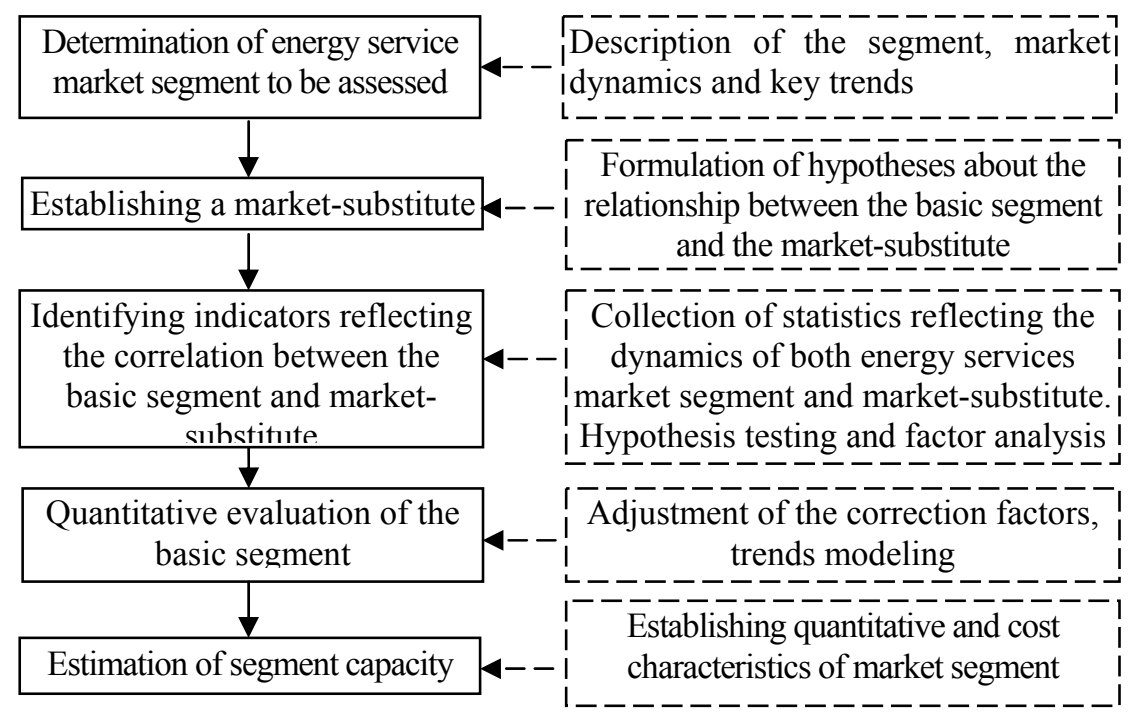

Figure 2: Estimating the capacity of an energy service market.

It is also important for energy service companies to be involved in the development of future organizational and economic innovation in the electricity industry. One example of such innovations are very widespread demand-side management programs (DSM), the implementation of which requires the involvement of all stakeholders of the energy and leads to an increase in ESCO system integration. DSM is a set of measures for load management for end-users 
(usually based on financial incentives through the time-of-use tariffs for electricity) or energy efficiency investments [2, 10]. The essence of demand management consists in energy utility focusing on volume, structure and operating modes of energy consumption in the served region. Moreover, programs can be very different from the classic (for example, equipping commercial sector with energy efficient air conditioning, application of high electricity tariffs during peak hours or installation of reactive power compensators at enterprises) to the nontraditional (for example, stimulating the low energy consuming production of brown rice and promote it in school feeding in Thailand [6]). Table 2 shows how ESCOs may be involved on different DSM projects stages.

Table 2: Participation of ESCOs in the implementation of DSM programs.

\begin{tabular}{|l|l|}
\hline \multicolumn{1}{|c|}{ Stage } & \multicolumn{1}{c|}{ Participation of ESCOs } \\
\hline $\begin{array}{l}\text { Selection of sites for } \\
\text { the implementation of } \\
\text { DSM project }\end{array}$ & $\begin{array}{l}\text { ESCOs are contractors to conduct energy audits on } \\
\text { selected objects }\end{array}$ \\
\hline $\begin{array}{l}\text { Development of the } \\
\text { program design }\end{array}$ & $\begin{array}{l}\text { ESCOs assess costs, form the budget of programs, } \\
\text { select suppliers of energy efficient equipment }\end{array}$ \\
\hline $\begin{array}{l}\text { Implementation of } \\
\text { DSM program }\end{array}$ & $\begin{array}{l}\text { ESCOs test and install the equipment, carry out } \\
\text { project management, provide the monitoring of the } \\
\text { project results }\end{array}$ \\
\hline $\begin{array}{l}\text { Analysis of the DSM } \\
\text { program results }\end{array}$ & $\begin{array}{l}\text { ESCOs develop recommendations for extension and } \\
\text { expansion of the range of objects for future DSM } \\
\text { projects }\end{array}$ \\
\hline
\end{tabular}

It should be noted that the effective implementation of the demand-side management concept depends on applying to utilities a number of administrative and legal impact measures, since, as described above, they have little incentive to the development of related services.

\section{Conclusion}

The energy service market model, proposed in the study, eliminates the economic and institutional barriers ESCOs faced in developing countries that have arisen as a result of restructuring in power industry. The model promotes the growth of service quality, increase of reliability of the basic equipment of power plants and transmission facilities, improving energy efficiency of industry processes and economies of developing countries as a whole. The model also removes some investment barriers and promotes technological modernization of the power industry in developing countries. 


\section{References}

[1] Demand-side management in China. Benefits, barriers and policy recommendations; Natural Resources Defence Council. http://www.nrdc.org/air/energy/chinadocs/dsm.pdf.

[2] Gitelman, L.D., Ratnikov, B.E., Kozhevnikov, M.V. \& Shevelev U.P., Demand-side management. Promising innovation for the Russian electric power industry, [in Russian], Economy: Moscow, 2013.

[3] IFC Energy Service Company Market Analysis. http://www.ifc.org/wps/ wcm/connect/dbaaf8804aabab1c978dd79e0dc67fc6/IFC+EE+ESCOS+Ma rket+Analysis.pdf?MOD=AJPERES.

[4] Energy Service Companies in China: The Role of Social Networks and Trust; Frankfurt School of Finance \& Management. http://www.frankfurtschool.de/clicnetclm/fileDownload.do?goid=000000302332AB4.

[5] Demand-side Management Strategies and the Residential Sector: Lessons from International Experience; University of Cambridge, Electricity Policy Research Group. https://www.repository.cam.ac.uk/handle/1810/242085.

[6] DSM in Thailand. A case study; Joint UNDP/World Bank Energy Sector Management Assistance Programme. http://timetable.cput.ac.za/_other_ web_files/_cue/DUE/2001/PDF/singh.pdf.

[7] Energy efficiency policies around the world: review and evaluation; World Energy Council Report. http://www.worldenergy.org/documents/energy efficiency_final_online.pdf.

[8] Demand Side Management in India. The 11th Annual Asia Power \& Energy Congress Report. http://www.cccindia.co/corecentre/Database/ Docs/DocFiles/dsmpaper.pdf.

[9] Kozhevnikov, M.V. Estimation of energy service capacity market, [in Russian]. Bulletin of the Samara State University of Economics, 5, pp. 55-60, 2013.

[10] Gitelman, L.D., Ratnikov, B.E. \& Kozhevnikov, M.V. Demand-side management for energy in the region, [in Russian]. Economy of Region, 2, pp. 71-78, 2013. 